\title{
Students' Attitude Towards the Digitalization of Bangladesh
}

\author{
Md. Masud Rana, Md. Julfikar Ali \\ Department of Management Studies, Begum Rokeya University, Rangpur, Bangladesh
}

Email address:

Masud_brur@yahoo.com (Md. M. Rana),julfikar05.bd@gmail.com (Md. J. Ali)

\section{To cite this article:}

Md. Masud Rana, Md. Julfikar Ali. Students' Attitude Towards the Digitalization of Bangladesh. International Journal of Economics, Finance and Management Sciences. Vol. 4, No. 3, 2016, pp. 127-137. doi: 10.11648/j.ijefm.20160403.15

Received: April 11, 2016; Accepted: April 19, 2016; Published: May 3, 2016

\begin{abstract}
The study scrutinized the "Students' Attitude towards the Digitalization of Bangladesh". It is positive attitude result is shown towards the digitalization of Bangladesh. By the increasing of computer uses, internet uses, ICT knowledge enlargement, and the modern technology uses for different sectors, is the finest achievement of Bangladesh. By this study is explored that students is thanking about the several facts of digitalization; education sector, health sector, communication sector, different services sector are one of them to contemplate about the digital means. From class five to post -graduation level of Bangladesh are the concerning staple of this study to evaluate by using some methods to find the attitude of the students' about the appearing benefits of the digitalization of Bangladesh there reveled positive attitude mostly.
\end{abstract}

Keywords: Digitalization, Positive Attitude, ICT

\section{Introduction}

Bangladesh is a technologically rising country in the world. The proportion of using ICT is increasing day by day. In recent year it is a common point is that "Digital Bangladesh". Digitalization is the integration way of digital technologies into the daily life by the digitalizing of everything or that can stand by the modern and update technologies. The Present government of Bangladesh manifests a plan to make Bangladesh digitalize, it is the amalgamation plan that to assist Bangladesh as a country of digitalization by 2021 . But it is a very logical matter is the how the young generation or student is informatively perceived the concentrative matter of digitalization, it is an indispensible part is now to the human being of the world to think about the modern technology by the increasing number of using technology and the overall condition of the country defines how they able to take the advantages of sophistication technologies. The prospect of the young generation so to say student expectation is very crucial to make it fruitful for that their attitude towards the digitalization of Bangladesh. From class five to post graduation level is the vast place where their students how think about the digitalization and how they want to see the digitalization a developing country like Bangladesh. The study have been selected some student from the different places of Bangladesh with judging the, school, college, public, university, private university at the as to location to magistrate the students' attitude towards the digitalization of Bangladesh.

\section{Theoretical Framework of the Study}

Digitalization:

According to Oxford dictionary-"The conversion of text, pictures, or sound into a digital form that can be processed by a computer: the digitization of the rare map collection at the library". [1]

Business dictionary stated that- "Conversion of analog information in any form (text, photographs, voice, etc.) to digital form with suitable electronic devices (such as a scanner or specialized computer chips) so that the information can be processed, stored, and transmitted through digital circuits, equipment, and networks. See also digitalization". [2]

Attitude:

According to merriam-webster-"the way you think and feel about someone or something, a feeling or way of 
thinking that affects a person's behavior, a way of thinking and behaving that people regard as unfriendly, rude, etc." [3]

Vision -21:

"Vision 2021 was the political manifesto of the Bangladesh Awami League party before winning the National Elections of 2008. It stands as a political vision of Bangladesh for the year 2021, the golden jubilee of the nation. The policy has been criticized as a policy emblematic of technological optimism in the context of Bangladesh and the state repression of media, low internet penetration, inadequate electricity generation" explain Whither Digital Bangladesh (2015). [4]

Digitalization of Bangladesh:

Digital Bangladesh means digitalizing Bangladesh by ensuring an ICT based society where information will be available on line. Here all the possible tasks of government or semi-government will be performed using digital technology. The motto of digital Bangladesh is to establish technology based digital governance, e-commerce, e-agriculture, eproduction, e-education etc. explain -onlineeducare. [5]

\section{Objectives of the Study}

- To find the facets of Notions of Digitalization.

- To find the Awareness level of Digitalization of Bangladesh of students.

- To find the inclusive attitude about the Digitalization of Bangladesh.

- To acclaim from the overall statuses of digitalization of Bangladesh.

\section{Methodology of the Study}

\subsection{Assortment of the Population}

The population of this study included student whose are from class five to post graduation from different school, college, public and private universities in Dhaka, Chittagong, Rangpur in Bangladesh. It is considered that these places are well representing the overall perception of students of Bangladesh. Embrace that the population is representing the regarding area from the contemplation of urban and rural area.

\subsection{Sample}

Sample nominated by the method of considering from class 5-8, from class 9-12, graduation to post-graduation. There selected total 60 samples from the consideration of mentioned ranges. It is considered at least 10 samples from each segment and respondent is considered at randomly.

\subsection{Mechanism}

In this study, a questionnaire was designed for the better execution of this study. There designed 30 questions are set, some question are considered the Likert scale in five point's measurement and besides this common type questions with indication the mentioned answer, some dichotomy questions are set.

\subsection{Data Collection and Analysis}

With the designed questions and finding the effective results there considered primary basis data collection through direct questionnaire type and the help of Google Forms of survey. The questionnaire were analyze on the basis of collected data by the help of Statistical tools, general counting method and the SPSS-Version 20. In this study there used quantitative research methods so to say-frequencies, general statistical tools, for the purpose of finding the gist information about the students' attitude towards the digitalization of Bangladesh. The comparison point of view for considering the behavior more responsive result of opinion and the scaling questions consider two path agree and strongly agree are considered the positive or affirmative responsive and strongly disagree and disagree combinable define negative outlook. Neutral point the excluding the comparison point of positive and negative concern. It is considered that higher the value rationally of positive and negative contains the attitude positive or negative relates.

\subsection{Research Hypothesis}

There are four hypothesizes that are used to investigate some important factor of the attitude of digitalizing of Bangladesh.

H1: Having computer has significant link with the knowledge the digitalization of Bangladesh.

$\mathrm{H} 2$ : Using internet has significant link with the knowledge the digitalization of

Bangladesh.

H3: Digitalization can bring the great change has significant link with supporting the digitalization of Bangladesh.

H4: Great challenge for the government has significant link with supporting the digitalization of Bangladesh.

Assumptions: Knowledge the digitalization of Bangladesh and supporting the digitalization of Bangladesh are dependent variables, having computer, using intern, can bring great change, great challenge for the present government are considered independent variables.

Testing techniques and Tools using: By the help of Statistical Package for the Social Sciences (SPSS) version 20, one way ANOVA, F test value and significant value 5\% is considered. $\mathrm{P}<0.05$ is considered as the acceptance level.

In order to test these four hypothesis, it has been taken the details form the collected data.

\section{Reasoning of the Study}

It is the world of technologically hip so it is a stuff of apprehension is that how a country takes the opportunity of ICT. Bangladesh is a developing country and it possesses some qualities the improvement manner of technologically. It is an ample highlighted word is "Digital Bangladesh" because Bangladeshi government trying to make Bangladesh digital from the various calibers conducts for technological dashes. The people of Bangladesh is the ultimate opportunity 
users of the technology from different modus it is looked the social services sector, educational sector, medical sector, research sector, agricultural sector, communication sector, etc. all the sectors are working for the people of Bangladesh but question is that how much they expect and how much they getting. This study look the investigation of the young generation of Bangladesh specially the future generation to around students' whose are class from five to post graduation level. By this study it can be conceivable from the various aspects to distinguish the general behavior of students about the digitalization of Bangladesh. It is very much imperative to make a plan successful to validate the general characteristic of that plan and the investigational issues of the benefiters it is painstaking that the study cover this cite about the regarding staple of students' attitude towards the digitalization of Bangladesh.

\section{Discussion}

This study is allied about the attitude of the student about the digitalization of Bangladesh. To find this comportment there taken 60 population from different places of Bangladesh $\mathrm{N}=60$, male $=45$ that means $75 \%$ (table 1 ) on the other hand female $=15$ that encompasses $25 \%$ (table 1 ) of the overall. This responding criteria segmented 3 types -five to eight responded number is $20 \%$ (table 1 ), class $9-12$ responded measurement is $20 \%$ (table 1) and it is found that from graduation to post graduation level there responded level is $60 \%$ (table 1). And from the variables concern, It is recognized that 31 frequency level shown that they have computer that carries $51.7 \%$ (table 1) and on the finger 29 (table 1) frequencies shown their behavior they have no computer that contains $48.3 \%$ (table 1). Internet using circumstance $83.3 \%$ (table 1) student uses internet by way and $16.7 \%$ (table 1) student are negatively shown their attitude they are not using internet. 68.3\% (table 1) student using their computer for the education purposes, $6.7 \%$ (table 1) using computer for entertainment purpose and $25 \%$ (table 1) student spring response for the others purpose, $96.7 \%$ (table 1) student evaluated that they have known the primary concern about the digitalization and 3.3\% (table 1) student felt that this is not well perceived for them. Grasped that about $96.7 \%$ (table 1) students felt well about the knowledge the digitalization of Bangladesh on the other arrow 3.3\% (table 1) student shown lacking or negative response it is gotten that digitalization and the digitalization of Bangladesh from two points of view gave the parallel point result from the similar percentage. Detected that 5\% (table 1) student cognizant about the digitalization as of their family and $36.7 \%$ (table 1) student grew the message from television and $25 \%$ (table 1) student taken the information primarily from the newspaper and $33.3 \%$ (table 1) informed from the others sources about the primary idea or primary conception of the digitalization. They perceived that, they are enjoying the digital means of facilities ofr different purposes of their daily life style and exposed reaction $93.3 \%$ (table 1) on the other needle some student clearly think that they are now getting any facilities its about $6.7 \%$ (table 1) at overall logic. $83.3 \%$ (table 1) revealed "Yes" in their educational institution give facilities as concern the tiniest to thoroughgoing nous and $11.7 \%$ (table 1) felt they remain not getting the minimum facility or any facilities for the digital means from their educational institution. By including the ICT education of the text book give the better effect to go the digitalization way, $95 \%$ (table 1) student trust that positive upshot it is very crucial part, on the other indicator 5\% student made known their outcome is not. About 55\% (table 1) of Bangladesh is not well informed about the digitalization; they are not slight intelligence of agreement of knowledge about the digitalization of Bangladesh on further finger $45 \%$ (table 1) family of the concerning tradition state that they are known about the digitalization of Bangladesh.

Table 1. Analysis of communal Issue of digitalization

\begin{tabular}{|c|c|c|}
\hline Variables & Frequency & Percent \\
\hline Gender & Frequency $(\mathrm{N})$ & Percent \\
\hline Male & 45 & $75 \%$ \\
\hline Female & 15 & $25 \%$ \\
\hline Class & Frequency & Percent \\
\hline $5-8$ & 12 & $20 \%$ \\
\hline $9-12$ & 12 & $20 \%$ \\
\hline Graduation- Post-Gradiuation & 36 & $60 \%$ \\
\hline Do you have any computer? & Frequency & Percent \\
\hline Yes & 31 & $51.7 \%$ \\
\hline No & 21 & $48.3 \%$ \\
\hline Do you use internet by any way? & Frequency $(\mathrm{N})$ & Percent \\
\hline Yes & 50 & $83.3 \%$ \\
\hline No & 10 & $16.7 \%$ \\
\hline $\begin{array}{l}\text { What is the purpose for using } \\
\text { Compueter? }\end{array}$ & Frequency $(\mathrm{N})$ & Percent \\
\hline Education & 41 & $68.3 \%$ \\
\hline Entertainment & 4 & $6.7 \%$ \\
\hline Others & 15 & $25 \%$ \\
\hline Do you kno what digitalizationn is? & Frequency $(\mathrm{N})$ & Percent \\
\hline Yes & 58 & $96.7 \%$ \\
\hline No & 2 & $3.3 \%$ \\
\hline $\begin{array}{l}\text { Do you know the digitalization of } \\
\text { Bangladesh? }\end{array}$ & Frequency $(\mathrm{N})$ & Percent \\
\hline Yes & 58 & $96.7 \%$ \\
\hline No & 2 & $3.3 \%$ \\
\hline $\begin{array}{l}\text { From whare you informed about the } \\
\text { digitalization? }\end{array}$ & Frequency $(\mathrm{N})$ & Percent \\
\hline Family & 3 & $5 \%$ \\
\hline Television & 22 & $36.7 \%$ \\
\hline Newspaper & 15 & $25 \%$ \\
\hline Others & 20 & $33.3 \%$ \\
\hline $\begin{array}{l}\text { Do you enjoy any facilities of Digital } \\
\text { Means? }\end{array}$ & Frequency $(\mathrm{N})$ & Percent \\
\hline Yes & 56 & $93.3 \%$ \\
\hline No & 4 & $6.7 \%$ \\
\hline $\begin{array}{l}\text { In your educational institutions are the } \\
\text { any facilities } \\
\text { that are giving you, for the } \\
\text { digatilzation? }\end{array}$ & Frequency $(\mathrm{N})$ & Percent \\
\hline Yes & 53 & $88.3 \%$ \\
\hline No & 7 & $11.7 \%$ \\
\hline $\begin{array}{l}\text { Focusing ICT in your text/book, is one } \\
\text { of the important } \\
\text { part for the digitalization of } \\
\text { Bangladesh? }\end{array}$ & Frequency $(\mathrm{N})$ & Percent \\
\hline Yes & 57 & $95 \%$ \\
\hline No & 3 & $5 \%$ \\
\hline
\end{tabular}




\begin{tabular}{lll}
\hline Variables & Frequency & Percent \\
\hline Is your Family well known/ informed & Frequency (N) & Percent \\
about the digitalization of Bangladesh? & 27 & $45 \%$ \\
Yes & 33 & $55 \%$ \\
No & \\
\hline
\end{tabular}

Digitalization is not a sole word to perform it is the integrated way to execute the some actions by possible to bring the modern facilities and technological advancing. It not the silly action that can satisfy the one part anticipation but the action of assimilate aids consulate. In Bangladesh it is very accustomed word now for several reasons but the question is that how they perceive if we look the perception of student, they think digitalization can bring the great change of life as the constrictive condition of Bangladesh about 50\% (table 2) students feel that highly needed that they are strongly agree and $46.7 \%$ (table 2 ) students consent their behavior as just the agree level that they have support on that and $1.7 \%$ (table 2) shown their neutral level and other case $1.7 \%$ (table 2) shown strongly disagree none of them shown the disagree level. Digitalization is very complicated process $15 \%$ (table 2) students strongly believe that $23.3 \%$ (table 2) think that it is general agree on the other hand $28.3 \%$ (table 2) shown neutral, $21.7 \%$ (table 2) shown disagree and $11.7 \%$ (table 2) student have their consent as the gave strongly disagree level. $48.3 \%$ student believe that information is not well enough of the digitalization of Bangladesh. $10 \%$ presented the highly agreement level, $15 \%$ (table 2 ) exposed neutral and $16.7 \%$ (table 2) students provided the opinion as negatively or disagree and $10 \%$ (table 2) perceive it as strongly disagree. Digitalization of Bangladesh is a long term process maximum $41.7 \%$ (table 2) student highly exposed and at general intellect, $40 \%$ (table 2) student clearly state that they are agree. impersonal is $11.7 \%$ (table 2), Incongruity level is $5 \%$ (table 2) and $1.7 \%$ (table 2) shown their behavior strongly disagree level. By the comprehending establishment of new technology Bangladesh, it is very pragmatic scène is that the people of Bangladesh now getting the benefit of digitalization. it is reported that $48.3 \%$ (table 2) student strongly opinion that digitalization giving the best support to the education now and $38.3 \%$ (table 2) student believe generally really it is helpful, and the neutral level is $10 \%$ (table 2) and 3.3\% (table 2) student gave the views as disagreement level at all. Using information and communication technology is very popular and well known conversation at the contemporary world, it is one of the great part of digitalization. In Bangladesh the student opinion that using ICT, at the communication area, medical services, social services, governmental services are the main sectors to trace the digital technology at overall modus 53.3\% (table 2) students agreed about the opinion, $31.7 \%$ (table 2) shown strongly agreed, neutral is $8.3 \%$, disagree is $3.3 \%$ (table 2) and $3.3 \%$ (table 2) student opinion strongly disagree. It is observed that $50 \%$ (table 2) student believed that there give more priority to the digitalization of education and health sector, $40 \%$ gave positively agree and 5\% (table 2) gave neutral opinion $3.3 \%$ (table 2 ) and $1.7 \%$ (table 2) \& shown the disagree and strongly disagree at the giving more priority on health and education sector. It is the crucial factor is that the present government of Bangladesh is working on the behavior of making Bangladesh as a digital country, 11.7\% (table 2) student said that strongly as positive nature $18.3 \%$ gave general agree at that statement on the others hand $20 \%$ (table 2) shown the neutral behavior, 36.7\% (table 2) shown the negative behavior at general sense and $13.3 \%$ (table 2) gave the highly disagree level about the governmental support at all. $10 \%$ (table 2) and $51.7 \%$ (table 2) students exposed the strongly and general agreement level respectively and $26.7 \%$ (table 2 ) gave neutral behavior, $10 \%$ (table 2) gave negative and $1.7 \%$ (table 2) shown highly negative behavior as the concerning matter of digitalization help us to make our country more independent of others for the technologically dependent concern. With the copping with the demanding situation the mentality of the Bangladesh student are changing now it is mentioned that educational institutions of Bangladesh providing the better support asking the student gave agree is $18.3 \%$ (table 2 ), strongly agree is $15 \%$ (table 2 ), neutral is $23.3 \%$ (table 2), Strongly disagree is $15 \%$ (table 2) and only disagree is $28.3 \%$ (table 2 ). On the basis of existing support of the class room of the student at digital scenario is about the good feeling to enjoy the class room in digital is strongly agree is $40 \%$ (table 2 ), agree is $41.7 \%$ (table 2), neutral is $13.3 \%$ (table 2 ), disagree is $3.3 \%$ (table 2 ) and the strongly disagree is $1.7 \%$ (table 2 ). To give more tend to the technological development of any country there required hu8me amount to amount not only the money there need highly skill manpower it is the study there concluded that skill manpower are available to make our country digitalize here strongly agree is $16.7 \%$ (table 2), agree is $20 \%$ (table 2), neutral is $8.3 \%$ (table 2), disagree is $40 \%$ (table 2), strongly disagree is $15 \%$ (table 2 ) at all. Investment is the inevitable part of any implementation, most of the Bangladesh, students support that need to invest more as general settlement is $46.7 \%$ (table 2), muscularly agree is $38.3 \%$ (table 2), nonaligned is $10 \%$ (table 2), disagree is $1.7 \%$ (table 2) and strongly disagree is $3.3 \%$ (table 2), Hazard is one of important factor to contemplate for any plan effecting besides there need to think highly is that there may have, many barriers, in the case of digitalization there observed that the outlook of the students about the prevailing many barrier of digitalizing of Bangladesh, strongly agree is $21.7 \%$ (table 2 ), agree is $40 \%$ (table 2), neutral is $25 \%$ (table 2) disagree is $6.7 \%$ (table 2) and strongly disagree is $6.7 \%$ (table 2 ) it is seen that directly $61.7 \%$ (table 2 ) student support to make country and $21.7 \%$ (table 2) agree to digitalize $15 \%$ (table 2) is neutral and strongly disagree is $1.7 \%$. (Table 2) Digitalization not very easy term for the developing country like Bangladesh about $45 \%$ student fell that and directly shown their general agree level in the case of it is the challenging task for the present government., 38.3\% (table 2) believed strongly the challenging for the government and $13.3 \%$ (table 2) \& shown neutral attitude, disagree and strongly disagree is $1.7 \%$ (table 2 ) at consecutive style. At the trending situation and the challenging action of the global perspective it is appreciated that about 33.3\% (table 2) agree 
that government is working fully to make our country digitalization and $13.3 \%$ (table 2) highly support agree and neutral level is $25 \%$ (table 2) on the others hand $23.3 \%$ (table 2) shown disagree and $5 \%$ (table 2) shown highly disagreement as the concerned matter of government is fully working on the digitalization. Bangladesh is a developing country so it is the staple of reason how the people will be took the opportunity of digitalization from the general student sense of Bangladesh it can bring the general public problems for several reasons $-15 \%$ (table 2) student wellthought-out it highly disagree and $15 \%$ (table 2) is general disagree, $23.3 \%$ (table 2) is neutral and 28.3\% (table 2) people feel that it will be the problem for several reasons, where $8.3 \%$ (table 2 ) highly agree this assumption.

Table 2. Analysis of the interactive concerns of Digitalization.

\begin{tabular}{|c|c|c|c|c|}
\hline Digitalization can bring the great changes of our life & Frequency & Percent & Statement & \\
\hline Strongly Disagree & 1 & $1.70 \%$ & & \\
\hline Disagree & 0 & 0 & $1.70 \%$ & $(-)$ ve \\
\hline Neutral & 1 & $1.70 \%$ & $1.70 \%$ & \\
\hline Agree & 28 & $46.70 \%$ & & \\
\hline Strongly Agree & 30 & $50 \%$ & $96.70 \%$ & $(+) \mathrm{ve}$ \\
\hline Digitalization is very complicated & Frequency & Percent & Statement & \\
\hline Strongly Disagree & 7 & $11.70 \%$ & & \\
\hline Disagree & 13 & $21.70 \%$ & $33.30 \%$ & $(-)$ ve \\
\hline Neutral & 17 & $28.30 \%$ & $28.30 \%$ & \\
\hline Agree & 14 & $23.30 \%$ & & \\
\hline Strongly Agree & 9 & $15 \%$ & $38.30 \%$ & $(+)$ ve \\
\hline We are not wel informed about the digitalization of Bangladesh & Frequency & Percent & Statement & \\
\hline Strongly Disagree & 6 & $10 \%$ & $2670 \%$ & () ye \\
\hline Disagree & 10 & $16.70 \%$ & $20.10 \%$ & (-) ve \\
\hline Neutral & 9 & $15 \%$ & $15 \%$ & \\
\hline Agree & 29 & 48.3 & & \\
\hline Strongly Agree & 6 & $10 \%$ & $58.30 \%$ & $(+) \mathrm{ve}$ \\
\hline Digitalization of Bnagladesh is a long term process & Frequency & Percent & Statement & \\
\hline Strongly Disagree & 1 & $1.70 \%$ & $6.70 \%$ & \\
\hline Disagree & 3 & $5 \%$ & $6.70 \%$ & $(-)$ ve \\
\hline Neutral & 7 & $11.70 \%$ & $11.70 \%$ & \\
\hline Agree & 24 & 40 & & \\
\hline Strongly Agree & 25 & 41.7 & $81.70 \%$ & $(+) \mathrm{ve}$ \\
\hline Digitalizing is helping to our education now & Frequency & Percent & Statement & \\
\hline Strongly Disagree & 0 & 0 & $3.30 \%$ & \\
\hline Disagree & 2 & $3.30 \%$ & $3.30 \%$ & $(-)$ ve \\
\hline Neutral & 6 & $10 \%$ & $10 \%$ & \\
\hline Agree & 23 & $38.30 \%$ & & \\
\hline Strongly Agree & 29 & $48.30 \%$ & $86.60 \%$ & $(+) \mathrm{ve}$ \\
\hline $\begin{array}{l}\text { Using ICT in education, communication, Medical services, Govermental } \\
\text { services areas are the common sectors to digitalize in Bangladesh }\end{array}$ & Frequency & Percent & Statement & \\
\hline Strongly Disagree & 2 & $3.30 \%$ & $6.70 \%$ & $(-)$ ve \\
\hline Disagree & 2 & $3.30 \%$ & $6.70 \%$ & $(-)$ ve \\
\hline Neutral & 5 & $8.30 \%$ & $8.30 \%$ & \\
\hline Agree & 32 & $53.30 \%$ & $85 \%$ & $(+)$ ye \\
\hline Strongly Agree & 19 & $31.70 \%$ & $85 \%$ & $(+) \mathrm{ve}$ \\
\hline Education and Health secctor should give more priority to digitalize & Frequency & Percent & Statement & \\
\hline Strongly Disagree & 1 & $1.70 \%$ & & () ye \\
\hline Disagree & 2 & $3.30 \%$ & $5 \%$ & $(-)$ ve \\
\hline Neutral & 3 & $5 \%$ & $5 \%$ & \\
\hline Agree & 24 & $40 \%$ & $90 \%$ & $(+)$ ye \\
\hline Strongly Agree & 30 & $50 \%$ & $90 \%$ & $(+) \mathrm{ve}$ \\
\hline Government support is enough to make Bnagladesh as digitalize country & Frequency & Percent & Statement & \\
\hline Strongly Disagree & 8 & $13.30 \%$ & & \\
\hline Disagree & 22 & 36.7 & $50 \%$ & $(-)$ ve \\
\hline Neutral & 12 & $20 \%$ & 20 & \\
\hline Agree & 11 & $18.30 \%$ & $30 \%$ & $(+)$ ye \\
\hline Strongly Agree & 7 & $11.70 \%$ & $30 \%$ & (+) ve \\
\hline $\begin{array}{l}\text { Digitalization helps us to make our country more independent of others of the } \\
\text { technological support }\end{array}$ & Frequency & Percent & Statement & \\
\hline Strongly Disagree & 1 & $1.70 \%$ & $11.70 \%$ & $(-)$ ve \\
\hline $\begin{array}{l}\text { Disagree } \\
\text { Neutral }\end{array}$ & $\begin{array}{l}6 \\
16\end{array}$ & $\begin{array}{l}10 \% \\
26.70 \%\end{array}$ & $26.70 \%$ & (-) ve \\
\hline Agree & 31 & $51.70 \%$ & & \\
\hline Strongly Agree & 6 & $10 \%$ & $61.70 \%$ & $(+) \mathrm{ve}$ \\
\hline My educational institute providing the better facility of Technology & Frequency & Percent & Statement & \\
\hline Strongly Disagree & 9 & $15 \%$ & $43.30 \%$ & $(-)$ ve \\
\hline
\end{tabular}




\begin{tabular}{|c|c|c|c|c|}
\hline Digitalization can bring the great changes of our life & Frequency & Percent & Statement & \\
\hline Disagree & 17 & $28.30 \%$ & & \\
\hline Neutral & 14 & $23.30 \%$ & $23.30 \%$ & \\
\hline Agree & 11 & $18.30 \%$ & & \\
\hline Strongly Agree & 9 & $15 \%$ & $33.30 \%$ & $(+)$ ve \\
\hline It's very good feeling to enjoy class in digital class room & Frequency & Percent & Statement & \\
\hline Strongly Disagree & 1 & $1.70 \%$ & $5 \%$ & () ye \\
\hline Disagree & 2 & $3.30 \%$ & $5 \%$ & $(-)$ ve \\
\hline Neutral & 8 & $13.30 \%$ & $13.30 \%$ & \\
\hline Agree & 25 & $41.70 \%$ & & \\
\hline Strongly Agree & 24 & $40 \%$ & $81.70 \%$ & $(+)$ ve \\
\hline Skill people are available to make our country digitalize & Frequency & Percent & Statement & \\
\hline Strongly Disagree & 9 & $15 \%$ & & \\
\hline Disagree & 24 & $40 \%$ & $55 \%$ & $(-)$ ve \\
\hline Neutral & 5 & $8.30 \%$ & $8.30 \%$ & \\
\hline Agree & 12 & $20 \%$ & & \\
\hline Strongly Agree & 10 & $16.70 \%$ & $26.70 \%$ & $(+) \mathrm{ve}$ \\
\hline More investment should give to digitalize of Bangladesh & Frequency & Percent & Statement & \\
\hline Strongly Disagree & 2 & $3.30 \%$ & & \\
\hline Disagree & 1 & $1.70 \%$ & $5 \%$ & $(-)$ ve \\
\hline Neutral & 6 & $10 \%$ & $10 \%$ & \\
\hline Agree & 28 & $46.70 \%$ & $85 \%$ & \\
\hline Strongly Agree & 23 & $38.30 \%$ & $85 \%$ & $(+) \mathrm{ve}$ \\
\hline Many barriers are prevailing to digitalize of our country & Frequency & Percent & Statement & \\
\hline Strongly Disagree & 4 & $6.70 \%$ & & \\
\hline Disagree & 4 & $6.70 \%$ & $13.40 \%$ & $(-)$ ve \\
\hline Neutral & 15 & $25 \%$ & $25 \%$ & \\
\hline Agree & 24 & $40 \%$ & & \\
\hline Strongly Agree & 13 & $21.70 \%$ & $61.70 \%$ & $(+) \mathrm{ve}$ \\
\hline I support to digitalize my country & Frequency & Percent & Statement & \\
\hline Strongly Disagree & 1 & $1.70 \%$ & & \\
\hline Disagree & 0 & 0 & $1.70 \%$ & $(-)$ ve \\
\hline Neutral & 9 & $15 \%$ & $15 \%$ & \\
\hline Agree & 13 & $21.70 \%$ & & \\
\hline Strongly Agree & 37 & $61.70 \%$ & $83.40 \%$ & $(+) \mathrm{ve}$ \\
\hline I think, It is a great challenge for the present government & Frequency & Percent & Statement & \\
\hline Strongly Disagree & 1 & $1.70 \%$ & 20. & \\
\hline Disagree & 1 & $1.70 \%$ & $3.40 \%$ & $(-)$ ve \\
\hline Neutral & 8 & $13.30 \%$ & $13.30 \%$ & \\
\hline Agree & 27 & $45 \%$ & $8360 \%$ & (+) ye \\
\hline Strongly Agree & 23 & $38.60 \%$ & $83.60 \%$ & $(+) \mathrm{ve}$ \\
\hline Government is fully working on the digitalization & Frequency & Percent & Statement & \\
\hline Strongly Disagree & 3 & $5 \%$ & & \\
\hline Disagree & 14 & $23.30 \%$ & $28.30 \%$ & $(-)$ ve \\
\hline Neutral & 15 & $25 \%$ & $25 \%$ & \\
\hline Agree & 20 & $33.30 \%$ & $4660^{\circ}$ & \\
\hline Strongly Agree & 8 & $13.30 \%$ & $46.60 \%$ & $(+) \mathrm{ve}$ \\
\hline Digitalization can bring many problems of the general people of Bangladesh & Frequency & Percent & Statement & \\
\hline Strongly Disagree & 9 & $15 \%$ & $40 \%$ & $(-)$ ve \\
\hline Disagree & 15 & $25 \%$ & & \\
\hline Neutral & 14 & $23.30 \%$ & $23.30 \%$ & \\
\hline Agree & 17 & $28.30 \%$ & $36.60 \%$ & $(+) \mathrm{ve}$ \\
\hline Strongly Agree & 5 & 8.3 & & \\
\hline
\end{tabular}

\subsection{Critical Analysis}

As from the complete standpoint it is identified that $75 \%$ is male and $25 \%$ is female. They remain from class five to postgraduation at different spaces of Bangladesh. Principally $51.7 \%$ (table 1) students have computer and they using it most for the education proposes that specify $68.3 \%$ (table 1 ). About $83.3 \%$ (table 1) students use internet for slightest nous any means. As the seeming stuff about $96.7 \%$ (table 1) known the information of digitalization that is very encouraging symbol. The information attainment sense around $5 \%$ (table 1) catch from the chief information of digital from kinfolk, 36.7\% (table 1) grow from television and $25 \%$ (table 1) grew the info from newspaper and $33.33 \%$ (table 1) caught the information from the others cradles. There a highly well-versed spring is television. In edifying bodies of them, there $88.3 \%$ (table 1) informed they're giving at nominal sagacity of digital services means of prospect. By counting the ICT in the text book or prospectus it is perceived that $25 \%$ (table 1) replied highly progressive comportment and confirmatory support. It is a fact is that $45 \%$ (table 1) students conversant about the digitalization and $55 \%$ depressingly about the digitalization at very. Digitalization can convey great changes of our life 
proclamation $46.7 \%$ (table 2 ) highly and $50 \%$ (table 2 ) reach agreement total $96.7 \%$ (table 2) as confident nature that means great changes can be happened by digitalization. $23.3 \%+15 \% \quad$ (table 2) $=38.3 \% \quad$ (table 2) bequeathed affirmative sustenance. It is byzantine and on the others hand $33.4 \%$ (table 2) show bad outlook. 58.3\% (table 2) publicized that constructive fauna about that they are they are well informed. Digitalization is a long term process it is ponders that about $81.7 \%$ (table 2) students that signposts that it is permanency for the Bangladesh like mounting country. About $86.6 \%$ (table 2) student alleged that there digitalization plateful the tutoring at now from different intellects. About $85 \%$ (table 2) at total gave the positive nature they think that using ICT in education communication, medical services, governmental services etc. As the substance of digitalization. $90 \%$ (table 2) student craved that there should elasticity focus the education and health sector to digitalize of Bangladesh Affirmatively. About 29.6\% (table 2) as the integrated manner upkeep that government care is well adequate and $50 \%$ (table 2) confirmation undesirable behavior. $61.7 \%$ (table 2) students gave encouraging attitude that digitalization can make Bangladesh more independent round the technological reliant on, $81.7 \%$ (table 2) student sensed that exists very satisfaction to adore class in digital class room. 55\% (table 2) student dictum there proficiency manpower of Bangladesh is not existing to make digitalize. $85 \%$ (table 2) provided the judgment to endow more for the digitalizing and on the others indicator $51.7 \%$ (table 2) reflect here are obstructions handiness. 83.4\% (table 2) backing to digitalization and it is a prodigious challenge for the existing government $45 \%$ (table 2) (table 2) approve and $38.3 \%$ (table 2 ) powerfully as the attitudinal case of the students. Government is copiously employed on the behalf of the digitalization there granted level is $33.3 \%$ (table 2) and $13.3 \%$ (table 2) muscularly settle at total $46.6 \%$ (table 2). $28.33 \%$ (table 2) at total disagreement level. It is the digitalization it may the problem for the common community that that $28.3 \%$ (table 2) usually and $8.3 \%$ (table 2) extremely on the other finger differ level is $25 \%$ (table 2) and stalwartly affect is $15 \%$ (table 2) at aggregate $40 \%$ (table 2 ).

\subsection{Discussion of Hypothesis}

Hypothesis 1: Having computer has significant link with the knowledge the digitalization of Bangladesh is the first hypothesis it is gotten that there is not significant relationship of computer having and the digitalization knowledge. It is observed that the knowledge of digitalization has not dependent on the variable having computer.

Table 3. $H 1$ test.

\begin{tabular}{llllll}
\hline ANOVA & & & & & \\
\hline & Sum of Squares & df & Mean Square & F & Sig. \\
\hline Between Groups & .071 & 1 & .071 & 2.220 & .142 \\
Within Groups & 1.862 & 58 & .032 & & \\
Total & 1.933 & 59 & & & \\
\hline
\end{tabular}

Hypothesis 2: Using internet has no significant link with the knowledge the digitalization of Bangladesh. as the indicating the dependent variable and independent variable it is gotten that digitalization of Bangladesh has not significantly depend on the using internet.

Table 4. H2 test

\begin{tabular}{llllll}
\hline ANOVA & & & & \\
\hline & Sum of Squares & df & Mean Square & F & Sig. \\
\hline Between Groups & .053 & 1 & .053 & 1.645 & .205 \\
Within Groups & 1.880 & 58 & .032 & & \\
Total & 1.933 & 59 & & & \\
\hline
\end{tabular}

H3: Digitalization can bring the great change has no significant link with supporting the digitalization of Bangladesh. Here considered that the dependent variable is to support the digitalization of Bangladesh and independent variable is it can bring a great change. There is no significant relationship between two variables.

Table 5. H3 test

\begin{tabular}{llllll}
\hline ANOVA & & & & & \\
\hline & Sum of Squares & df & Mean Square & F & Sig. \\
\hline Between Groups & 4.133 & 3 & 1.378 & 1.907 & .139 \\
Within Groups & 40.450 & 56 & .722 & & \\
Total & 44.583 & 59 & & & \\
\hline
\end{tabular}

H4: Great challenge for the government has no significant link with supporting the digitalization of Bangladesh. It is a great challenge for the present government is considered independent variable and support of digitalization of Bangladesh is considered dependent variable and found that there is no significant relationship between two variables. 
Table 6. $H 4$ test

\begin{tabular}{llllll}
\hline ANOVA & & & & \\
\hline & Sum of Squares & df & Mean Square & F & Sig. \\
\hline Between Groups & 3.563 & 4 & .891 & 1.194 & .324 \\
Within Groups & 41.020 & 55 & .746 & & \\
Total & 44.583 & 59 & & & \\
\hline
\end{tabular}

If we look the relationship from plotting the mean from two variable points of interpretation.

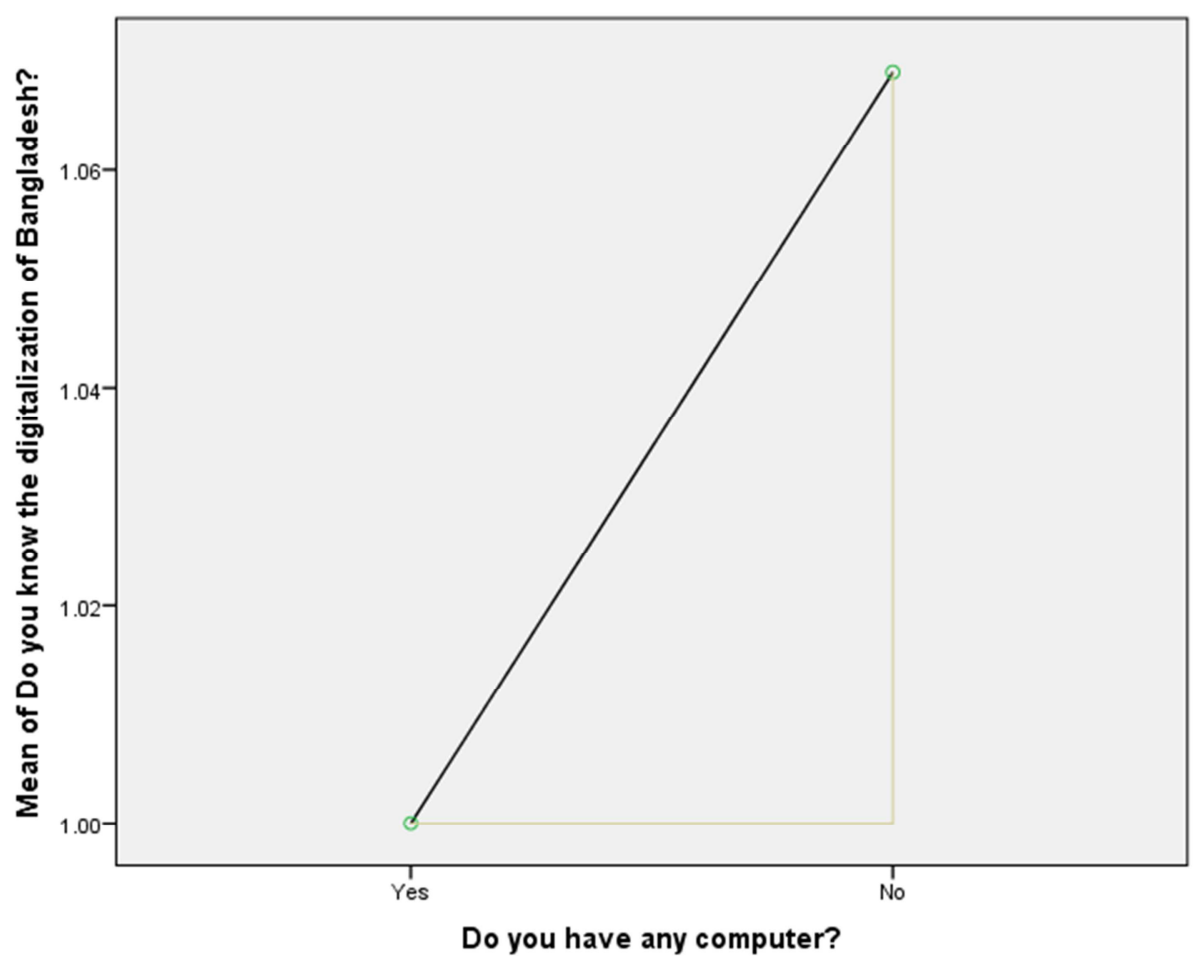

Figure 1. Mean plot of $H$.

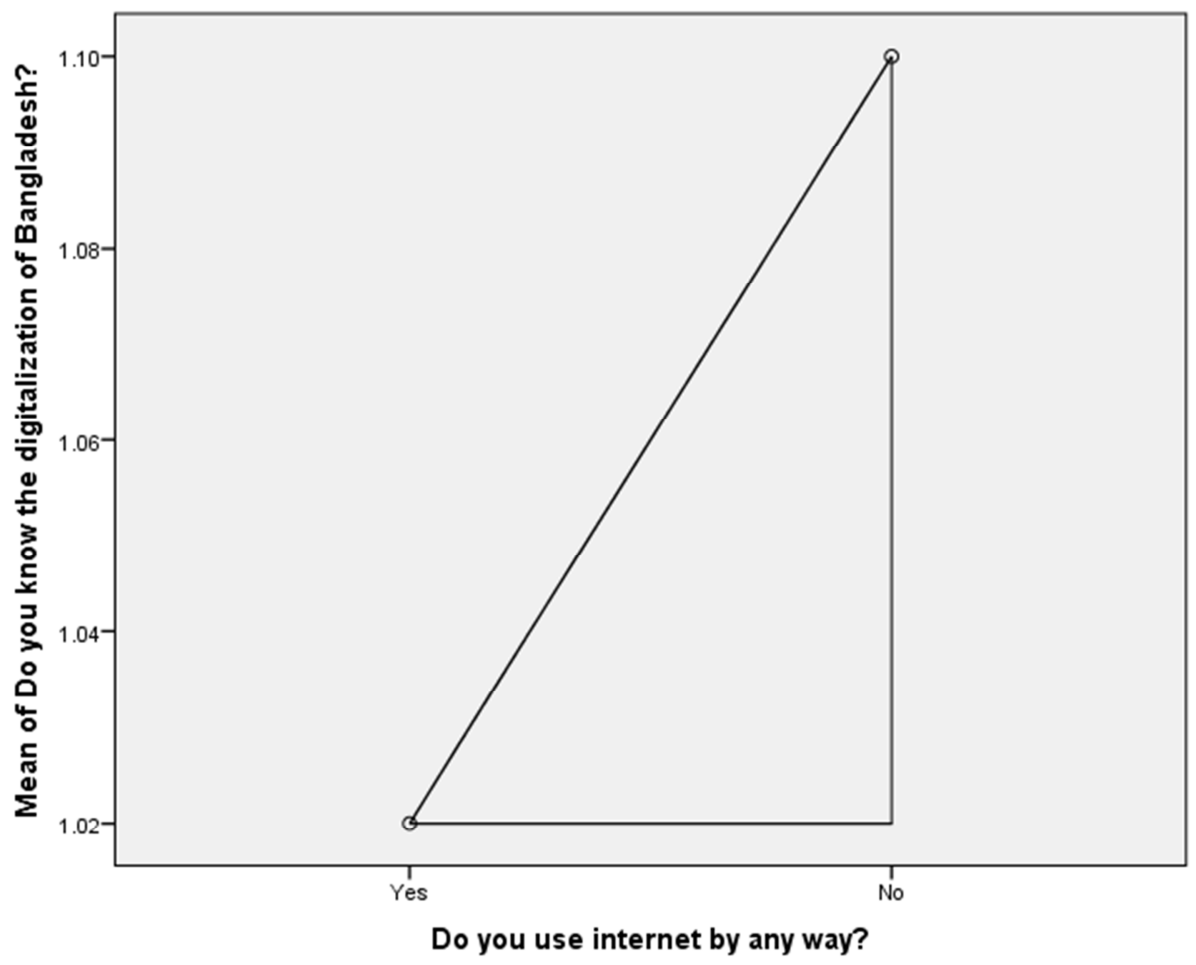

Figure 2. Mean plot of $\mathrm{H} 2$. 


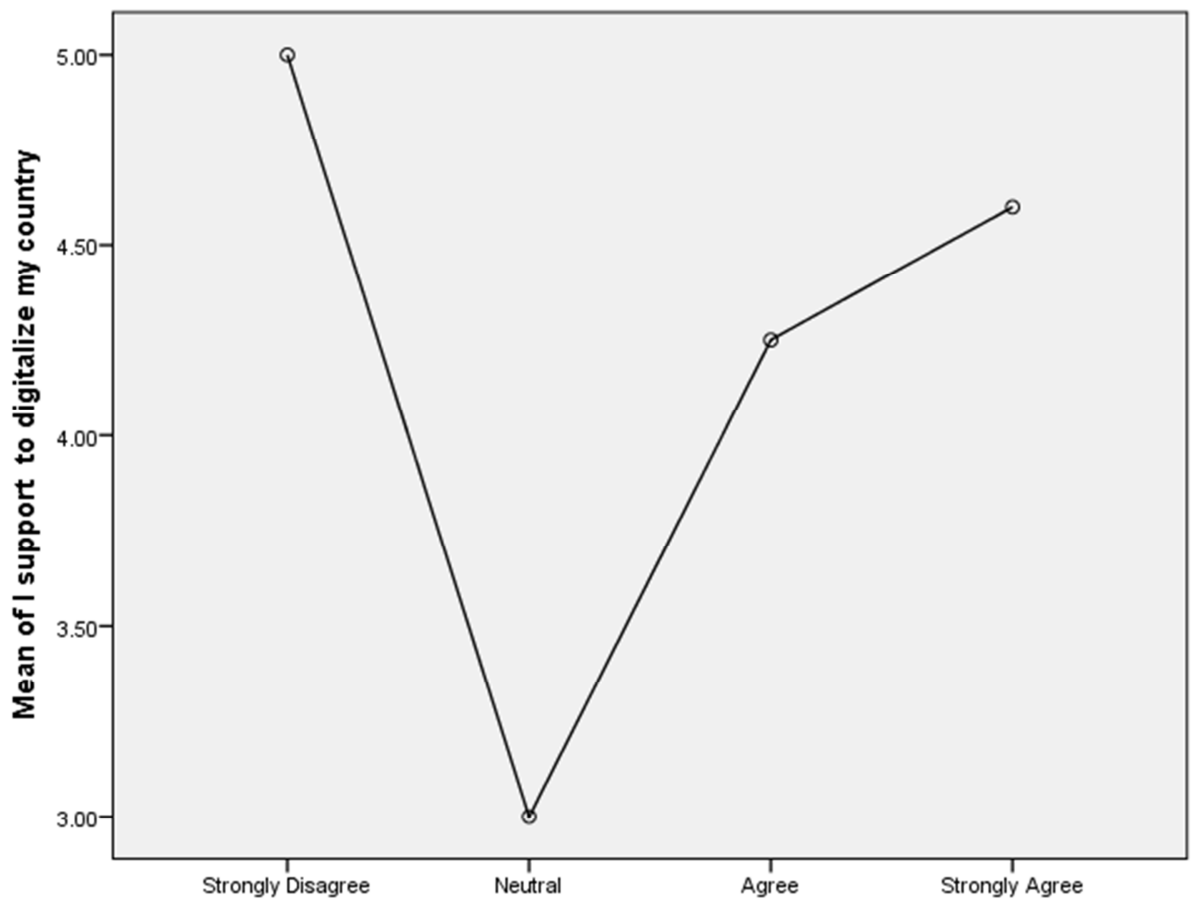

Digitalization can bring the great changes of our life

Figure 3. $\mathrm{H} 3$ mean plot.

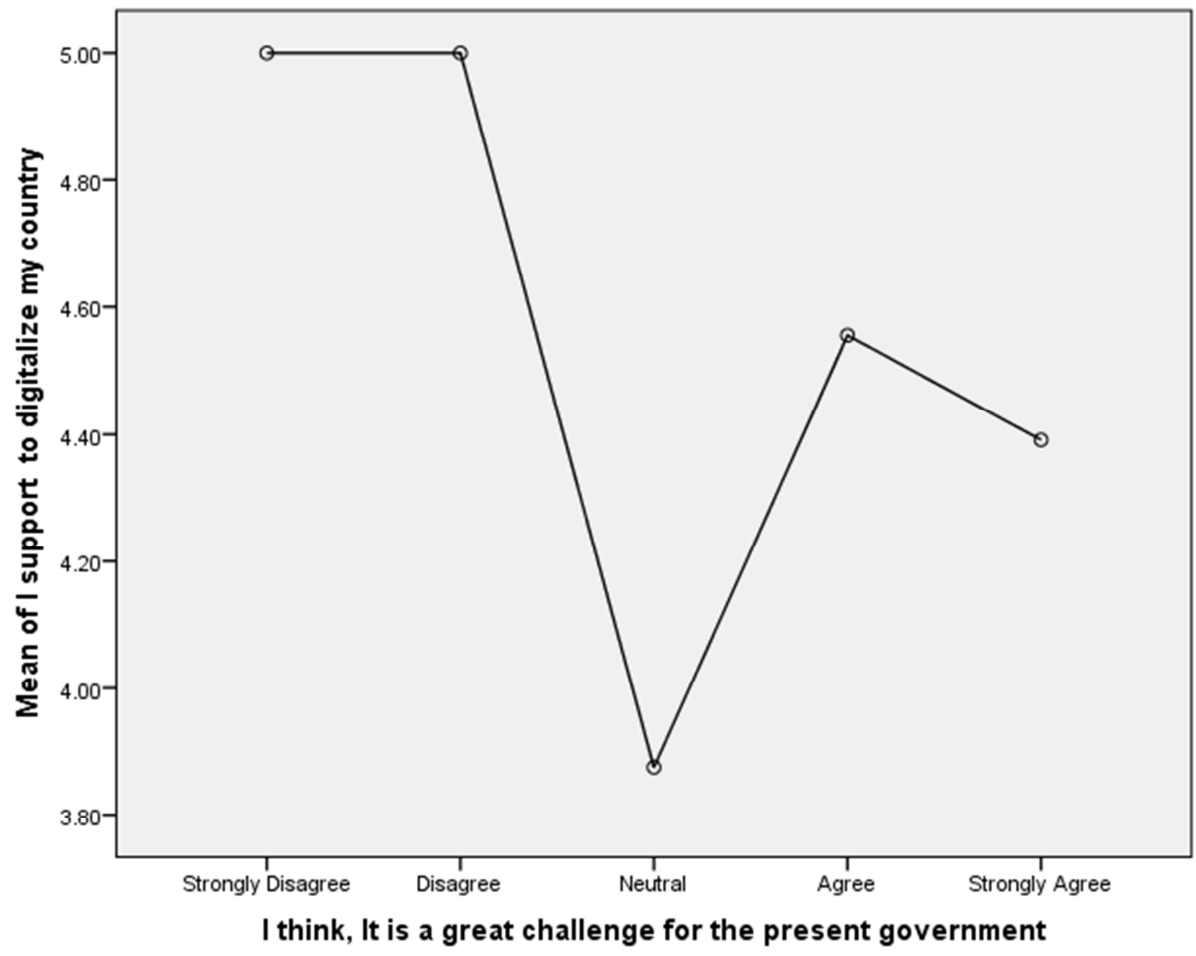

Figure 4. H4 mean plot.

At all with considering the one way ANOVA of the hypothesis test there dependent variable and independent variable shown the tested result and mean of the variables are shown at the association respectively, students' attitude measurement figure from the overall logic clear up the better investigation for considering $\mathrm{b}$ two factor positive and Negative comportment.

\section{Findings}

It is the world the world sophistication of technology. Bangladesh is trying to scope that global courtesy about the relevant to ICT expansion. The government of Bangladesh customary Vision-21 to brand Bangladesh digitalize as a country with bounding opportunity of using modern 
technologies. With keeping armistice in cognizance in this study it is originated that $51.7 \%$ (table 1) have computer of the student sort, about $83.3 \%$ (table 1) use inter for the purpose of education mostly $96.7 \%$ (table 1) student generally known the digitalization they know the information typically from television and the others sources. They feel superior good to get the digital means by anyway. Converging that every text book / curriculum there involved the ICT education offer them better sensitivity of ICT enhancement and singing imperative role to the digitalization. They furnished their attitude utmost their education bodies gave constructive support them to grow the digital mode. It is grasped that about 55\% (table 1) family are not well cognizant approximately the digitalization. From the hypothesis tested result it found there are no significant relationship between having computer (independent) and using internet (Independent) and the knowledge of digitalization of the Bangladesh (dependent) on the other hand it is figure out that two independent variables are: digitalization can bring great change and great challenge for the government consistent with the dependent variable supporting digitalization of Bangladesh there has no significant relationship. That means the tested result indicated the movement of streaming out look about the digitalization. rom the overall needle it is instituted that the student behaviors for the various fields are:

- Digitalization can bring great change -Mostly Positive attitude
- Digitalization is complicated-- Mostly Positive attitude

- Not well informed us- Mostly Positive attitude

- Long term process-Mostly Positive attitude

- Helping to education now-Mostly Positive attitude

- ICT in education, communication, medical services, social services- is digitalization - Mostly Positive attitude

- Should give more priority on health and education sector- Mostly Positive attitude

- Government support is enough- Mostly Negative attitude

- To make our country more independent from the technological concern- Mostly Positive attitude

- My education institutions giving facilities as concerning the minimum sense of technology- Mostly Negative attitude

- Good feelings to enjoy the digital class room- Mostly Positive attitude

- Available of skill manpower- Mostly Negative attitude

- More investment require-Mostly Positive attitude

- Barriers are prevailing - Mostly Positive attitude

- Support to digitalize-Mostly Positive attitude

- Challenge for the present government- Mostly Positive attitude

- Government working fully-Mostly Positive attitude

- will be the problem for the common people- Mostly Negative attitude

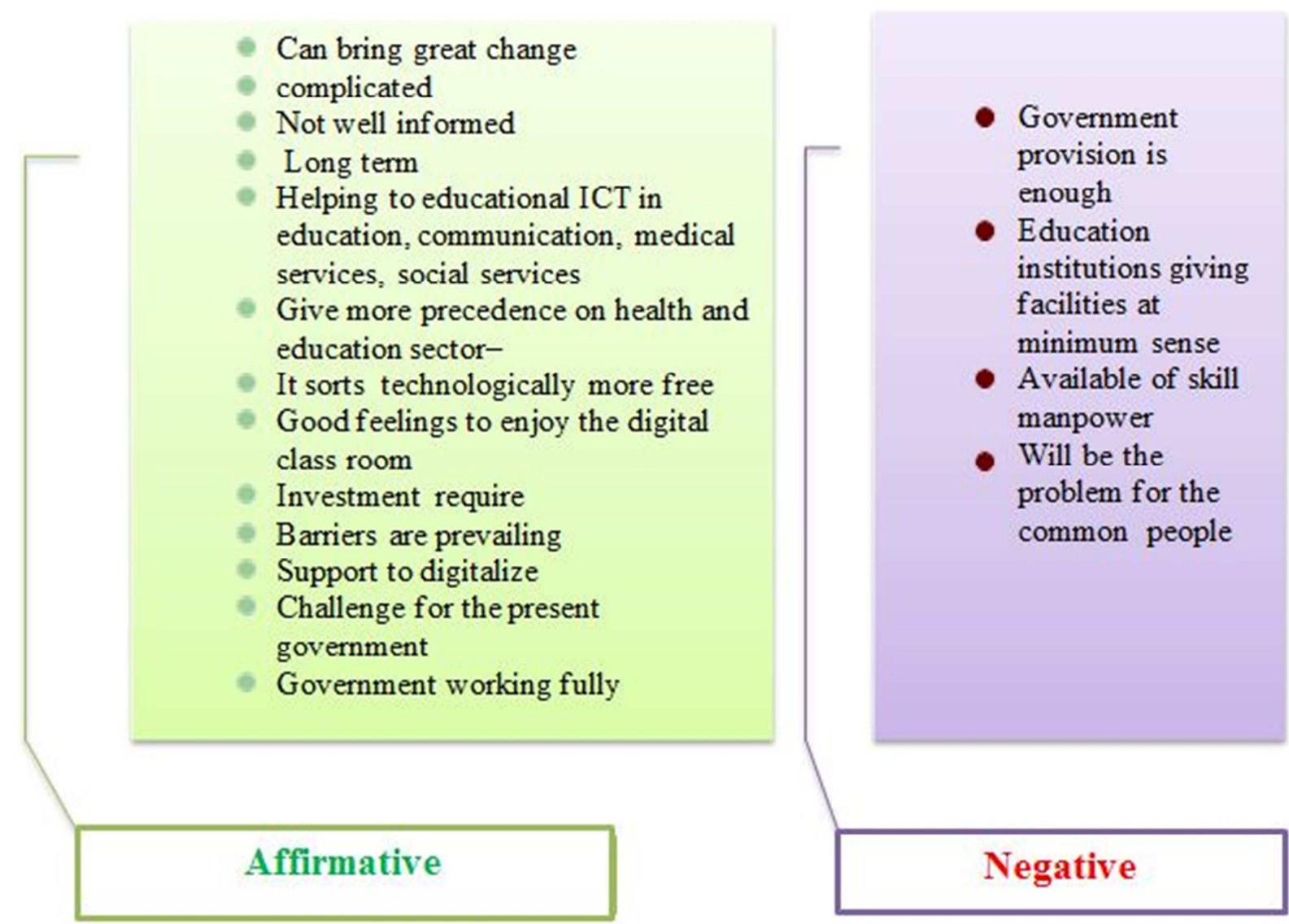

Figure 5. Attitude of students' about the digitalization of Bangladesh. 


\section{Conclusion and Recommendations}

All echo of the study is "Students' Attitude towards the Digitalization of Bangladesh" clinched that there mostly encouraging attitude for many reason about the digitalization of Bangladesh. The students are reasonably aware of the stylish realm of ICT for the proper using of ICT. The study shown that student are shown mostly affirmative opinion form the context of digitalization way and for the case of skill manpower, government support, some problems of the digital there seen negative opinion. The internet using rate, the computer using rate, the computer using purpose highly showed affirmative respond to the progression of digitalization of Bangladesh. Not only has this had the overall awareness level of the students comparatively increasing day by day. It is recommended that government should take more pragmatic action from the every sphere of development, it is really should give focus the attention, flat of digitalization glassy, on the education and health sector highly and others sector consecutively. An integrated action of the government with taking the help of expertise there gave focuses because it is seen lacking of know how People of Bangladesh and government should encourage more fund with the amalgamation support of altered organization. To sum up affirmative attitude of the students' of the study result is the pragmatic strive to find the digitalization tactic of poignant at the mounting nations form.

\section{References}

[1] http://www.oxforddictionaries.com/definition/english/digitizat ion

[2] http://www.businessdictionary.com/definition/digitization.htm l\#ixzz44nGBstDl

[3] http://www.merriam-webster.com/dictionary/attitude

[4] "Whither Digital Bangladesh?" The Khichuri. Retrieved 29 January 2015.

[5] http://onlineeducare.com/
[6] http://www.digitalworld.org.bd/digital-bangladesh-and-ict

[7] https://www.betterthancash.org/news/media-releases/makingdigital-bangladesh-vision-2021-a-reality-government-joinsthe-better-than-cash-alliance

[8] http://www.bd.undp.org/content/bangladesh/en/home/ourpersp ective/ourperspectivearticles/2015/07/09/transformingtowards-digitalization-of-bangladesh-judiciary.html

[9] http://www.thedailystar.net/supplements/24th-anniversary-thedaily-star-part-1/digital-bangladesh-dreams-and-reality-73118

[10] https://www.apc.org/en/blog/digital-bangladesh-primeministers-dream-vs-unders.

[11] http://www.albd.org/index.php/en/resources/specialreports/472-digital-bangladesh-a-dream-came-true

[12] http://www.huffingtonpost.com/brac/primary-schools-inbangla_b_9237224.html

[13] https://www.betterthancash.org/news/media-releases/makingdigital-bangladesh-vision-2021-a-reality-government-joinsthe-better-than-cash-alliance

[14] http://www.digital-bangladesh.com/

[15] http://www.a2i.pmo.gov.bd/digital-bangladesh

[16] http://www.gsma.com/publicpolicy/wpcontent/uploads/2012/03/Digital_Inclusion_and_Mobile_Sect or_Taxation_in_Bangladesh_1_pager_WEB.ppd $\bar{f}$

[17] http://www.mof.gov.bd/en/index.php?option=com_content\&vi $\mathrm{ew}=$ article $\& \mathrm{id}=321 \&$ Itemid $=1$

[18] http://www.prnewswire.com/news-releases/making-digitalbangladesh-vision-2021-a-reality-government-joins-thebetter-than-cash-alliance-300092247.html

[19] http://www.copenhagenconsensus.com/bangladeshpriorities/news/top-ideas-digital-bangladesh

[20] https://gurstein.wordpress.com/tag/digital-bangladesh/

[21] http://www.bdresearch.org.bd/home/index.php?option=com_c ontent\&view $=$ article\&id $=191$ :digitalbangladeshbangla\&catid=62:e-governance $\&$ Itemid $=105$ 